\title{
Prevalence of Bacterial Microbiota in Tilapia Guineensis Harvested from Buguma Brackish Water Environment River State, Nigeria
}

\author{
Ogbonne Fabian Chinedu*, Ayaobu-Cookey Ibifubara Kalada, Abdullahi Mohammed Mansur, \\ Matanmi Morufu Adewale
}

Department of Aquaculture, Nigerian Institute for Oceanography and Marine Research, Victoria Island, Lagos, Nigeria

Email address:

ogbonnefebian@yahoo.com (O. F. Chinedu)

${ }^{*}$ Corresponding author

\section{To cite this article:}

Ogbonne Fabian Chinedu, Ayaobu-Cookey Ibifubara Kalada, Abdullahi Mohammed Mansur, Matanmi Morufu Adewale. Prevalence of Bacterial Microbiota in Tilapia Guineensis Harvested from Buguma Brackish Water Environment River State, Nigeria. American Journal of Bioscience and Bioengineering. Vol. 8, No. 3, 2020, pp. 36-40. doi: 10.11648/j.bio.20200803.11

Received: March 26, 2020; Accepted: April 10, 2020; Published: June 17, 2020

\begin{abstract}
Brackish water fishes usually harbour human pathogenic bacteria particularly the enterics and coliform groups in their mucosal surfaces. Thus, this study was undertaken to investigate the prevalence of skin and gills microbiota of Tilapia guineensis as to understand their microbial assemblages and as well provide useful insights into the broad dynamics of the fish host-microbial relationship and health status. Thirty samples of Tilapia guineensis were collected from Buguma brackish water environment, River State, Nigeria. The skin and the gills of the tilapia were analyzed microbiologically. Specimen were collected by swabbing aseptically over the skin and gills segment of the fish and then processed for total bacterial count, followed by isolation and identification of isolated bacteria. Microbial load analysis revealed that the total viable count of bacteria ranged from 2.4 to $7.6 \times 10^{5} \mathrm{cfu} / \mathrm{ml}$ for skin and 2.1 to $5.7 \times 10^{6} \mathrm{cfu} / \mathrm{ml}$ for gills, and it was observed to fall within the recommended microbiological standard safety limit. A total of thirty-seven (37) bacteria, belonging to fifteen different genera in the family of Vibrionaceae, enterobacteriaceae and Morganellaceae were isolated from the fish. The prevalent rate of the bacterial shows that Proteus vulgaris recorded the highest frequency of occurrence of $16.22 \%$, followed by Vibrio parahaemolyticus with $10.81 \%$ occurrence and Provindencia rettgeri, Serratia mercescens and Salmonella sp. trailed them with $8.11 \%$. Kluyyera ascorbate, Citrobacter amalonaticus, Proteus mirabilis, Enterobacter aerogenes, plesiomonas shigelloides and Pseudomonas $s p$. have the least frequency of occurrence with $2.7 \%$ respectively for each. Though the bacterial count of Tilapia guineensis harvested from the water and fish sample did not exceed the standard recommended safety limit. There were several potential pathogenic and spoilage bacteria isolated as part of the fish flora. The presence of these bacteria could poses or constitute a public health risk.
\end{abstract}

Keywords: Bacterial Flora, Tilapia guineensis, Prevalence, Brackish Water, Pathogen

\section{Introduction}

Tilapia Guineensis is a widespread fish species with great aquaculture potentials in all the tropical and sub-tropical regions of the world [1]. Tilapia Guineensis have been classified prominent in the ecology of tropical waters as well as in the resources of their aquatic systems [2]. Tilapia Guineensis is very common in the brackish water zone of Nigeria and most especially in the Niger Delta region [3]. There is an increasing interest in the Tilapia guineensis production due to their several nutritional advantage of being firm in texture, possession of low cholesterol and relatively easy to cook [4]. Regardless of these numerous advantages, Tilapia guineensis and other fish species in general are susceptible to contamination with pathogenic bacterial organisms because of their flesh texture, their living habits as well as their habitant which is loaded with pathogenic bacteria. Among these pathogenic bacteria are the Vibrio sp., Aeromonas sp., Edwardsiella sp., and Salmonella sp., which belong to water and food borne group of pathogens. These 
bacteria are widely distributed in brackish water environment and they have been implicated as opportunistic pathogens causing gastroenteritis and other severe health conditions to man. Their occurrence has been reported in some African, Asian, European countries and virtually across the globe. Several researchers have reported that the release of pathogenic bacteria in faeces dispersed into aquatic environments can contaminate fish and shellfish harvested from these waters [5]. Once these bacteria are in the aquatic environment, plasmid exchange between the bacteria will be readily facilitated and can result in a higher frequency of multiple antibiotic resistant strains which perhaps could exert selective pressures to influence the antibiotic resistance [6].

Bacteria, a large group of single-celled, prokaryotic and ubiquitous microscopic organisms whose single cells have neither a membrane bounded nucleus nor other membrane bounded organelles like mitochondria and chloroplasts [7]; and are noted for most fish diseases, fish spoilage and threats to public health [8].

Evaluation of the prevalence of bacterial microbiota associated with the skin and gills of Tilapia guineensis harvested from brackish water environment usually give information on the relationship between the fish and the environment. Moreover, Water with high organic load have been reported to predisposes fish to disease condition [9]. Therefore, this study was embarked on to investigate the prevalence of bacterial microbiota associated with the skin and gills of Tilapia guineensis caught from Buguma brackish water environment.

\section{Materials and Methods}

Thirty (30) fish samples of Tilapia guineensis were collected from Buguma brackish water environment, River State, Nigeria, and transported in an oxygenated bag to Nigerian Institute for Oceanography and Marine Research, Lagos, where the skin and the gills of the fish sample were aseptically swabbed with a sterile swab stick for bacteriological studies.

\subsection{Total Bacteria Count Analysis}

Swabs were aseptically taking from the gills and skin of the fish with a clean sterile swab stick. The swabs were immersed into a $100 \mathrm{ml}$ conical flask containing buffered peptone water $(0.1 \%)$ (Merck, Germany). After overnight incubation for 18 hours at $37^{\circ} \mathrm{C}, 1 \mathrm{ml}$ was transferred for further analysis from the peptone water to Tryptone soy agar. Ten- fold serial dilutions $\left(10^{-5}\right)$ were carried out, and viable bacterial counts of the samples were obtained.

\subsection{Bacterial Enumeration and Identification}

Enumeration of bacteria was carried out using spread plate method. The plates containing Tryptone Soy Agar (Himedia, India) were inoculated and incubated at $37^{\circ} \mathrm{C}$ for 24 hours after which the discrete colonies were observed and subcultured to get pure colonies of the isolates. Pure colonies of the isolates were further sub-cultured on Eosin methylene blue (EMB) agar, Salmonella-Shigella agar, Thiosulfate Citrate bile salts sucrose (TCBS) agar and Mannitol salt agar. The bacteria isolates were identified using some parameters such as Gram staining reaction, cultural and morphological characteristics, and series of biochemical tests to confirm the presence of the suspected microorganism by their reactions to the tests according to Bergey's manual of determinative bacteriology, 8th Edition [10].

\section{Results}

Total bacteria count result of water sample, skin and gills of Tilapia guineensis from Buguma brackish water, River State are shown in Table 1. The bacterial load from the skin are significantly lower $(\mathrm{P}<0.05)$ than the bacteria count from the gills and the water sample. The highest microbial load was observed in the water sample, followed by the gills. All the bacterial isolated from the water sample, skin and gills of Tilapia guineensis from Buguma are shown in Table 2.

Table 1. Total bacteria count from the Gills, Skin and Brackish Water Sample from Buguma, River State.

\begin{tabular}{llll}
\hline Sample & Total bacteria count $(\mathbf{c f u} / \mathbf{m l})$ & Range & Mean \\
\hline Skin & $34.2 \times 10^{5}$ & $2.4-7.6 \times 10^{5}$ & $5 \times 10^{5}$ \\
Gills & $26.3 \times 10^{6}$ & $2.1-5.7 \times 10^{6}$ & $4 \times 10^{6}$ \\
Water & $29.4 \times 10^{6}$ & $3.3-8.5 \times 10^{6}$ & $6 \times 10^{6}$ \\
\hline
\end{tabular}

Table 2. Bacterial isolates obtained from Water, Skin and Gills of Tilapia guineensis from Buguma, River State.

\begin{tabular}{ll}
\hline Sample & Bacterial Isolates \\
\hline \multirow{2}{*}{ Skin } & Proteus vulgaris, Pseudomonas sp., Flavimonas oryzihabitans, Salmonella sp., Aerobacter aerogens, Serratia mercescens, \\
& Enterobacter aerogenes, Morganella morganii, Vibrio parahaemolyticus, Salmonella sp., Vibrio metschnikovii. \\
Gills & Shigella sp., Shigella sonnei, Proteus vulgaris, plesiomonas shigelloides, E. coli, Morganella morganii, Proteus mirabilis, Vibrio \\
& metschnikovii, Vibrio parahaemolyticus, Serratia mercescens, Provindencia rettgeri. \\
Water & Provindencia rettgeri, Serratia mercescens, E. coli, Kluyyera ascorbate, Citrobacter amalonaticus, Vibrio parahaemolyticus, \\
& Salmonella sp., Citrobacter freundii. \\
\hline
\end{tabular}

The cultural and morphological characteristics used in the identification processes of the bacterial isolates from Buguma are represented in Table 3. Table 4 shows the Gram stain reaction and biochemical tests for presumptive confirmation of the bacterial isolates obtained from the gills and skin of the fish samples. Table 5, on the other hand represent the percentage frequency of occurrence of the bacterial isolates from Tilapia guineensis. 
Table 3. Cultural and Morphological Characteristics of bacterial isolates of Tilapia guineensis from Buguma, River State.

\begin{tabular}{|c|c|c|}
\hline Bacterial isolates & Colonial characteristics & Cell morphology under microscope \\
\hline Proteus vulgaris & Circular and convex with Swarming motility & Appeared as negative short rod \\
\hline Pseudomonas sp. & Circular shape with raised undulate margin & Cell appears as asporogenous negative rod \\
\hline Flavimonas oryzihabitans & Rough shape with yellow pigment & Appeared as negative rod. \\
\hline Salmonella sp. & Translucent colony with black center & Appears negative straight rod. \\
\hline Aerobacter aerogens & Shiny, convex colony with entire margins. & Appears negative short rod \\
\hline Serratia mercescens & $\begin{array}{l}\text { Pinpoint circular and mucoid colony with entire margins and umbonate } \\
\text { elevation }\end{array}$ & Cells appear as negative short rod-shape \\
\hline Morganella morganii & Circular shape with opaque colour & Appears negative straight rod \\
\hline Vibrio parahaemolyticus & Circular blue-green colony & Appears negative curved-rod \\
\hline Vibrio metschnikovii & Greyish, opaque colony & Appears slightly curved-rod \\
\hline Shigella sp. & Small, circular convex, smooth and transparent colony & Appears negative short rod \\
\hline plesiomonas shigelloides & Round ended, greyish, shiny colony with smooth surface & Appears negative straight rod. \\
\hline Escherichia coli & Large, thick, greyish white, moist and smooth opaque colony & Appears negative short rod \\
\hline Provindencia rettgeri & Large, dull grey colony & Appears negative straight rod \\
\hline Kluyyera ascorbate & Small circular colony with entire edge & Appears negative straight rod \\
\hline Citrobacter amalonaticus & Low, smooth, convex and moist translucent colony & Appears negative rod \\
\hline
\end{tabular}

Table 4. Biochemical tests and Gram stain reaction of bacterial isolates of Tilapia guineensis from Buguma, River state.

\begin{tabular}{|c|c|c|c|c|c|c|c|c|c|c|c|}
\hline \multicolumn{2}{|c|}{ Isolates Code } & Organ & \multicolumn{2}{|c|}{ Gram reaction } & morphology & Motility & \multicolumn{2}{|c|}{ Oxidase } & Glucose & Lactose & \multirow{2}{*}{$\begin{array}{l}\text { Maltose } \\
+\end{array}$} \\
\hline RM1 & & skin & $-\mathrm{ve}$ & & rod & + & - & & + & + & \\
\hline RM2 & & Skin & $-\mathrm{ve}$ & & rod & - & - & & + & + & + \\
\hline RM3 & & Skin & -ve & & rod & + & - & & + & - & - \\
\hline RF2 & & Skin & -ve & & rod & + & - & & + & - & - \\
\hline RF1 & & Skin & $-\mathrm{ve}$ & & rod & + & + & & + & + & + \\
\hline RF2 & & Gill & -ve & & $\operatorname{rod}$ & - & - & & + & - & - \\
\hline RF3 & & Gill & $-v e$ & & $\operatorname{rod}$ & - & - & & + & - & - \\
\hline RM4 & & Gill & $-v e$ & & rod & + & + & & + & - & - \\
\hline RF4 & & Gill & -ve & & rod & + & - & & + & - & - \\
\hline RF5 & & Gill & -ve & & rod & + & - & & + & - & - \\
\hline RM5 & & Skin & $-v e$ & & rod & + & - & & + & + & + \\
\hline RM6 & & Gill & $-\mathrm{ve}$ & & rod & + & - & & + & + & + \\
\hline RM7 & & Gill & -ve & & Curve-rod & + & - & & + & - & - \\
\hline RF6 & & Skin & $-v e$ & & rod & + & - & & + & - & - \\
\hline RF7 & & Skin & $-v e$ & & rod & + & - & & + & - & - \\
\hline RM8 & & Skin & $-\mathrm{ve}$ & & Curve-rod & + & - & & + & - & - \\
\hline RM9 & & skin & -ve & & $\operatorname{rod}$ & + & - & & + & + & + \\
\hline RM10 & & skin & -ve & & rod & + & - & & + & + & + \\
\hline RM11 & & Gill & $-\mathrm{ve}$ & & Curve-rod & + & - & & + & - & - \\
\hline RM8 & & Gill & $-\mathrm{ve}$ & & rod & + & - & & + & + & + \\
\hline RF9 & & Gill & $-\mathrm{ve}$ & & $\operatorname{rod}$ & + & - & & + & - & - \\
\hline RF10 & & Gill & $-\mathrm{ve}$ & & $\operatorname{rod}$ & + & + & & + & + & + \\
\hline RF11 & & Gill & -ve & & rod & - & - & & + & - & - \\
\hline $\mathrm{H}_{2} \mathrm{~S}$ & Gas p & uction & Citrate & Me & yyl red & Voges-proskauer & Indole & & duction & Catalase & Organism isolated \\
\hline+ & - & & + & + & & - & + & + & & + & Proteus vulgaris \\
\hline+ & _- & & + & - & & - & - & - & & - & Pseudomonas sp. \\
\hline - & + & & + & - & & - & + & - & & + & Flavimonas oryzihabitans \\
\hline - & + & & - & + & & - & - & - & & + & Salmonella sp. \\
\hline+ & - & & + & - & & + & - & + & & + & Aerobacter aerogenes \\
\hline - & + & & - & - & & - & - & - & & - & Shigella $s p$. \\
\hline - & - & & + & - & & - & - & + & & - & Providencia rettgeri \\
\hline - & + & & - & - & & - & + & - & & + & Plesiomonas shigelloides \\
\hline - & - & & - & + & & - & + & - & & - & E. coli \\
\hline - & + & & - & + & & - & + & - & & + & Morgenella morganii \\
\hline - & + & & + & + & & - & + & - & & - & Kluyyera ascorbata \\
\hline+ & + & & + & - & & - & - & + & & + & Proteus mirabilis \\
\hline - & + & & - & + & & + & + & - & & - & Vibrio metschnikovii \\
\hline - & + & & + & - & & + & + & - & & - & Serratia marcescens \\
\hline - & + & & - & + & & - & + & - & & + & Morgenella morganii \\
\hline+ & + & & - & - & & - & + & - & & - & Vibrio parahaemolyticus \\
\hline+ & - & & + & + & & - & + & + & & + & Proteus vulgaris \\
\hline+ & - & & + & + & & - & + & + & & + & Proteus vulgaris \\
\hline+ & + & & - & - & & - & + & - & & - & Vibrio sp. \\
\hline+ & + & & + & - & & - & - & + & & + & Proteus mirabilis \\
\hline
\end{tabular}




\begin{tabular}{|c|c|c|c|c|c|c|c|c|}
\hline $\mathrm{H}_{2} \mathrm{~S}$ & Gas production & Citrate & Methyl red & Voges-proskauer & Indole & Nitrate reduction & Catalase & Organism isolated \\
\hline- & + & + & - & + & + & - & - & Serratia marcescens \\
\hline+ & + & + & + & - & - & - & - & Citrobacter freundi \\
\hline- & - & + & - & - & - & + & - & Providencia rettgeri \\
\hline
\end{tabular}

Table 5. Frequency of occurrence of bacterial isolates in Tilapia guineensis from Buguma, River State.

\begin{tabular}{lll}
\hline Bacterial Isolates & Number of Occurrence & Percentage of Occurrence \\
\hline Proteus vulgaris & 6 & 16.22 \\
Pseudomonas sp. & 1 & 2.70 \\
Flavimonas oryzihabitans & 2 & 5.41 \\
Salmonella sp. & 3 & 8.11 \\
Aerobacter aerogens & 1 & 2.70 \\
Serratia mercescens & 3 & 8.11 \\
Enterobacter aerogenes & 1 & 2.70 \\
Morganella morganii & 2 & 5.41 \\
Vibrio parahaemolyticus & 4 & 10.81 \\
Vibrio metschnikovii & 2 & 5.41 \\
Shigella sp. & 2 & 5.41 \\
plesiomonas shigelloides & 1 & 2.70 \\
E. coli & 2 & 5.41 \\
Proteus mirabilis & 1 & 2.70 \\
Provindencia rettgeri & 3 & 8.11 \\
Kluyyera ascorbate & 1 & 2.70 \\
Citrobacter amalonaticus & 1 & 2.70 \\
Citrobacter freundi & 1 & 2.70 \\
Total & 37 & 100 \\
\hline
\end{tabular}

\section{Discussion}

Total bacteria count in brackish water sample, skin and gills of the Tilapia guineensis varies significantly. The bacterial load in each of the sample analyzed was high but does not exceed the standard microbiological recommended limit. The high bacterial load in each of the sample segment could be as a result of high temperature where the fish samples were collected which is close to optimum temperature for several mesophilic bacterial [10]. Total bacteria load in the gills ranged from 2.1 to $5.7 \times 10^{6}, 2.4$ to $7.6 \times 10^{5}$ for the skin and 3.3 to $8.5 \times 10^{6}$ for the water sample. High bacteria load observed from this study is in agreement with the study of [11] who reported the presence of high bacterial load in tilapia gills, but in contrast with the work of Chessbrought [12], who reported that bacteria associated with the gills are actively maintained at low level to enable the fish keep the bacterial number low, and therefore afford the fish some degree of protection against bacterial invasion by the gills micro flora.

The bacterial flora from the water sample, skin and gills of Tilapia guineensis were majorly gram negative bacteria belonging to the family of enterobacteriaceae, Vibrionaceae and Morganellaceae, and it is a reflection of the bacteria composition from their environment. This finding is in agreement with an earlier report by Al-Harbi and Uddin [13] that the microflora of caught fish and other aquatic specimens is largely a reflection of the microbial quality of the water where they were harvested. The microflora of Tilapia guineensis harvested from Buguma brackish water environment include: Proteus sp., Pseudomonas sp., Flavimonas oryzihabitans, Salmonella sp., Aerobacter aerogens, Serratia mercescens, Enterobacter aerogenes, Morganella morganii, Vibrio parahaemolyticus, Salmonella sp., Vibrio metschnikovii, Shigella sp., Provindencia rettgeri, E. coli, Kluyyera ascorbate, and Citrobacter species. Nganou Donkeng et al. [14] reported different bacterial species in their study of Characterization of bacterial flora of tilapia harvested from four lakes in the north of Cameroon. Proteus sp., Serratia mercescens, Vibrio species, Salmonella sp., Morganella morganii, Provindencia rettgeri dominated other bacterial groups in the water sample, skin and gills of the Tilapia guineensis as shown in Table 2. However, the commensal bacterial flora from this fish is a facultative opportunistic pathogen which under stress could give rise to fish disease and could as well be zoonotic in nature. Salmonella sp., E. coli, Shigella sp., and Vibrio $s p$. have been implicated in so many fish borne infection of human.

A total of thirty-seven [37] bacteria, belonging to fifteen different genera in the family of Vibrionaceae, enterobacteriaceae and Morganellaceae were isolated from the fish sample [15].

The prevalence rate shows that Proteus vulgaris recorded the highest frequency of occurrence of $16.22 \%$, followed by Vibrio parahaemolyticus with $10.81 \%$ occurrence and Provindencia rettgeri, Serratia mercescens and Salmonella $s p$. trailed them with $8.11 \%$. Kluyyera ascorbate, Citrobacter amalonaticus, Proteus mirabilis, Enterobacter aerogenes, plesiomonas shigelloides and Pseudomonas $s p$. have the least frequency of occurrence with $2.7 \%$ respectively for each. In conclusion, Though the bacterial count of Tilapia guineensis harvested from the water and fish sample did not exceed the standard recommended limit. There were several potential pathogenic and spoilage bacteria isolated as part of the fish 
flora. The presence of these bacteria could poses or constitute a public health risk. This study showed that the Tilapia guineensis and the water sample from Buguma brackish water environment host a ridiculous and diverse bacterial flora. However, Microbiota of fishes and brackish water from Buguma, River State, Nigeria is mainly composed of Gramnegative bacilli.

\section{References}

[1] Owusi-Frimpong, M., Attipoe, F. U. K. and Padi, J. N. (2005). Comparison of some traits of economic importance in Tilapias with particular reference to their culture in Ghana. NAGA 22: 33-38.

[2] Akinwumi, F. O. (2001). Food and feeding habits of Tilapia zilli in Ondo State University fish farm. In: Eyo A, Ajao EA (eds) Conference Proceedings of Fisheries Society of Nigeria, Maiduguri, Nigeria, pp 12-18.

[3] Ajiboye, O. O. and Yakubu, A. F. (2010). Some aspects of biology and aquaculture potentials of Tilapia guineensis (dumeril) in Nigeria. Review of Fish Biology and Fisheries 20: $441-455$.

[4] Shinkafi, S. A and Ukwaja, V. C. (2010). Bacteria Associated with Fresh Tilapia Fish (Oreochromis niloticus) Sold at Sokoto Central Market in Sokoto, Nigeria. Nigerian Journal of Basic and Applied Science 18 (2): 217-221.

[5] De Sousa, J. A., Silva-Souza, A. T. (2001). Bacterial community associated with fish hand water from Congonhas River, Sertneja, parana, Brazil. Brazilian Archives of biology and Technology 44: 373-381.

[6] Trust, T. J, and Sparrow, R. A. H. (1974). The bacterial flora in the alimentary tract of freshwater salmonid fish. Canadian Journal of Microbiology 20: 1219-1228.

[7] Fredickson, B. L., Brown, S., Cohn, M. A., Conway, A., Crosby, C., McGovern, M. and Mikels, J. (2004). $5^{\text {th }}$ annual meeting of society for personality and social psychology Austin, Texas on Finding positive meaning and experiencing positive emotions build resilience. Symposium presented at the functional significance of positive emotions; 29th -31 st January, pp 6.
[8] Ashbolt, N. J., Grabow, W. O. K, and Snozzi, M. (2001). Indicators of microbial water quality. In: Fewtrell L, Bartram J, eds. Water quality: Guidelines, standards and health Assessment of risk and risk management for water-related infectious disease. WHO Water Series. London, IWA Publishing, 34. 289-315.

[9] Abidemi-Iromini, A. O. and Fofah, O. J. (2016). Bacteria Occurrence in Sarotherodon malarotheron and Chrysichthys nigrodigitatus in Brackish Water Environment. Applied Tropical Agriculture 21 (1): 1- 6.

[10] Sheyin, A. N and Solomon, K. J. (2017). EndoMicrobial Fauna of Tilapia spp. (Oreochromis niloticus) found in a flowing Canal at Eden Garden and Park Utako, Abuja. Journal of Fisheries and Livestock Production 5 (1): 1 - 8.

[11] Bergey, R. E; Buchanan and Gribbons, N. E. (1974). Bergey's Manual of Determinative Bacteriology (8th edition). Williams and Wilkins Co. Baltimore USA.

[12] Al-Harbi, A. H., and Uddin, M. N. (2007): Seasonal Trends in Gill Bacterial Flora of Hybrid Tilapia, Oreochromis niloticus $\times$ O. aureus. Journal of Applied Aquaculture 19: 1: 61-70.

[13] Nganou Donkeng, N., Maiwore, J., Tatsadjieu, L., Ngoune, D., Montet, C. and Mbofung, M. F. (2011). Characterization of the bacterial flora of tilapia (Oreochoromis niloticus) harvested from four lakes in the north of Cameroon. African Journal of Biotechnology 10 (71): 16016-16023.

[14] Al-Harbi, A. H. and Uddin, M. N. (2005). Bacterial diversity of tilapia (Oreochromis niloticus) cultured in brackish water in Saudi Arabia. Aquaculture 250: 566-572.

[15] Chessbrought, J. T. (2006) Characterization of Bacteria in fishes. Journal of Applied Science Research in the Tropics 7: 78-82.

[16] Al-Harbi, A. H., and Uddin, M. N. (2003). Quantitative and qualitative studies on bacterial flora of hybrid tilapia (Oreochromis niloticus $\times \mathrm{O}$. aureus) cultured in earthen ponds of Saudi Arabia. Aquaculture Research 34: 43-48.

[17] Ofimer (2002). Tilapia and Nile perch. Alternatives on the market of poissonblanc. http://www.ofimer.fr/PDF/obseco/11_noteshemp_e_dou ce.PDF. 